\title{
Wild and Farmed Sea Bass (Dicentrarchus Labrax): Comparison of Biometry Traits, Chemical and Fatty Acid Composition of Fillets
}

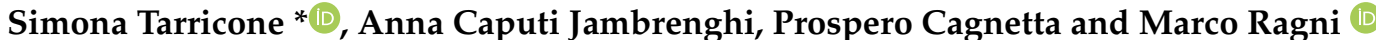

Department of Agricultural and Environmental Science, University of Bari Aldo Moro, 70125 Bari, Italy; anna.caputijambrenghi@uniba.it (A.C.J.); prosperocagnetta@gmail.com (P.C.); marco.ragni@uniba.it (M.R.)

* Correspondence: simona.tarricone@uniba.it

check for updates

Citation: Tarricone, S.; Caputi Jambrenghi, A.; Cagnetta, P.; Ragni, M. Wild and Farmed Sea Bass (Dicentrarchus Labrax): Comparison of Biometry Traits, Chemical and Fatty Acid Composition of Fillets. Fishes 2022, 7, 45. https://doi.org/10.3390/ fishes7010045

Academic Editor: Vittorio Maria Moretti

Received: 28 January 2022

Accepted: 8 February 2022

Published: 11 February 2022

Publisher's Note: MDPI stays neutral with regard to jurisdictional claims in published maps and institutional affiliations.

Copyright: (C) 2022 by the authors. Licensee MDPI, Basel, Switzerland. This article is an open access article distributed under the terms and conditions of the Creative Commons Attribution (CC BY) license (https:// creativecommons.org/licenses/by/ $4.0 /)$.

\begin{abstract}
Sea bass is a fish widely produced, consumed and appreciated in Italy. Its intensive rearing system provides the consumption of valuable fish to a wider population. Thanks to the use of an appropriate feed, it is possible to obtain reared sea bass which are richer in total lipid with a majority presence of polyunsaturated fatty acids, such as n- 3 and n- 6 series. In this study, a total of 75 specimens of European sea bass coming from three different origins (two farmed and one wild) were considered, with 25 fish from each origin. Biometry traits were valued as of the chemical and fatty acid profile of fillets. Biometric indices, proximate composition and fatty acid percentage were significantly affected by the rearing system. Fishes from the intensive rearing system (IRS) showed the highest value of relative profile and condition factor, a higher content of lipid and total n- 6 that influenced the n-6/n-3 ratio and the atherogenic indexes, and values that indicated their flesh for human consumption as a healthy alternative to the wild fishes.
\end{abstract}

Keywords: sea bass; biometric traits; fatty acid; chemical composition; fish quality

\section{Introduction}

The aquaculture industry has been experiencing an expansion in the last few decades due to the high demand of fresh sea bass in the European market [1]. The traditional fishery is suffering from catch decline due to overfishing and habitat deterioration. Fish farming offers the chances to control the quality of the entire production process and to obtain a final product with quality attributes as close as possible to those of wild fish [2].

The effect of rearing conditions may have a crucial role in fish growth and in the morphometric ratios of fish, which may affect the amount of the edible portion [3]. Moreover, the visual appearance is an important attribute for the consumer/buyer and becomes even more important in the case of fish species of large commercial trade such as the small-sized (300 g) European sea bass. Many studies have stated that in addition to its economical characteristics, sea bass provides positive contributions to human health $[4,5]$.

Furthermore, the basic compositional traits are the result of a complex set of characteristics, such as chemical and fatty acid composition [6]. The nutritional value and organoleptic characteristics of fish are particularly affected by rearing conditions [7]; therefore, the composition and sensory parameters are expected to be different between wild and farmed fish [8]. In farmed fish, commercial diets affect fish growth rate as well as flesh composition $[9,10]$. In addition, the chemical and fatty acid composition of farmed sea bass may be modulated qualitatively and quantitatively, within certain limits, through the formulation of feeds with high levels of n-3 polyunsaturated fatty acids (PUFA) [11-13]. Seafood products are, in fact, the only significant source in the human diet of polyunsaturated fatty acids, in particular, those of the n-3 series (eicosapentaenoic acid, 20:5n-3; docosahexaenoic acid, 22:6 n-3). These are precursors of hormone-like molecules with anti-thrombogenic and anti-atherogenic properties, and they play a fundamental role in 
the development of neural and visual functions [14]. Dietary manipulation of farmed sea bass may contribute to enriched flesh with an increased amount of polyunsaturated fatty acids, such as those of the n-3 and n- 6 series [15-17].

The objective of this study was to evaluate the effect of the sea bass (Dicentrarchus labrax) rearing system (intensive vs. extensive) in comparison with captured fish on biometry traits, chemical composition and fatty acid profile of fillets.

\section{Materials and Methods}

A total of 75 specimens of European sea bass were used; 25 animals were wild and captured from traditional fishing in the low Adriatic Sea $\left(39^{\circ} 56^{\prime} 30.7^{\prime \prime} \mathrm{N} 18^{\circ} 50^{\prime} 12.7^{\prime \prime} \mathrm{E}\right)$, whereas 50 were obtained from two rearing systems, among which 25 fishes from an Apulian commercial farm representative of the extensive rearing system (ES) and 25 specimens from an intensive rearing system in tanks (IRS). The extensive rearing system was performed in a salt lake connected to the Adriatic Sea $\left(40^{\circ} 12^{\prime} 15.4^{\prime \prime} \mathrm{N} 18^{\circ} 27^{\prime} 24.0^{\prime \prime} \mathrm{E}\right)$ which included fish coming in from the sea and fish transferred as juveniles in the lake. The fishes received food supply until they were about one year old; afterwards, they were fed exclusively on the resource available in the aquatic environment. The intensive rearing system was performed in rearing plants with tanks supplied with continuous seawater flows $(35 \%$, $10 \mathrm{~L} / \mathrm{min})$; fishes were fed twice a day with a commercial pelleted feed. In both farmed groups, a commercial pelleted diet containing fish meal, fish oil, soybean meal, wheat meal, yeast, vitamin and mineral mix was administered (Table 1 ). The fishes analyzed from the ES and IRS farming systems were 36 and 24 months old, respectively.

Table 1. Chemical and fatty acid composition of feed (\%).

\begin{tabular}{cc}
\hline Proximate Composition (\% on DM Basis) & $\%$ \\
\hline Moisture & 10.0 \\
Crude protein & 50.0 \\
Total lipid & 18.5 \\
Ash & 9.0 \\
Crude fibre & 1.5 \\
\hline Fatty acid composition (\% FA methyl esters) & $\%$ \\
\hline C14:0 (myristic) & 5.1 \\
C15:0 (pentadecanoic) & 0.4 \\
C16:0 (palmitic) & 15.8 \\
C18:0 (stearic) & 5.1 \\
C16:1 n7 (palmitoleic) & 5.4 \\
C18:1 n9 (oleic) & 16.5 \\
C20:1 n9 (eicosanoic) & 2.9 \\
C18:2 n6 (linoleic) & 11.3 \\
C18:3 n6 ( $\gamma$ - linolenic) & 1.1 \\
C18:3 n3 ( $\alpha$-linolenic) & 1.9 \\
C18:4 n3 & 1.6 \\
C20:4 n6 (arachidonic, ARA) & 0.7 \\
C20:5 n3 (eicosapentaenoic, EPA) & 7.9 \\
C22:5 n6 (docosapentaenoic, DPA) & 0.3 \\
C22:5 n3 & 0.4 \\
C22:6 n3 (docosahexaenoic, DHA) & 10.2 \\
\hline
\end{tabular}

Wild fish (WF) were caught in the low Adriatic Sea by the local fishing technique. Wild and farmed fish were caught by net, selected according to their market size $(\approx 300 \mathrm{~g})$ and slaughtered by immersing in ice-cold water (hypothermia), as required by the laws in force [18]. Fish sampling was performed during August 2019. 


\subsection{Proximate Composition of Feed}

The pelleted feed was analysed to determine the chemical and fatty acid composition (Table 1). Feed samples were ground in a hammer mill with a $1 \mathrm{~mm}$ screen and evaluated using the following association of Official Agricultural Chemistry AOAC [19] procedures: moisture content (method 930.15), total lipid (method 920.39), ash (method 942.05), crude protein (method 954.01), crude fibre (method 945.18).

\subsection{Sample Treatment and Analysis}

In the day of caught, dead fishes were delivered to the laboratory in refrigerated conditions $\left(4^{\circ} \mathrm{C}\right)$.

Upon arrival, fish were singularly weighed for total body weight (TBW) using a $0.01 \mathrm{~g}$ precision balance. Hence, the following measurements were made, using a digital caliper (0.1 cm precision scale): total, fork and head length and maximum height [20]. From linear and weight measurements, morphometric indexes, as relative profile $(100 \times$ maximum height/fork length), cranial index $(100 \times$ head length/fork length) and condition factor $\left(100 \times\right.$ bodyweight/total length $\left.{ }^{3}\right)$ were calculated. All the specimens were dissected, and carcass, head, skin, viscera and fillet weight were individually recorded to calculate the relative somatic indexes and commercial yield (\% of total weight).

On the analysis's day, fillets were rapidly thawed, then skinned, chopped, combined in a pool, homogenized and lyophilized, after cooling to $-80{ }^{\circ} \mathrm{C}$ for $48 \mathrm{~h}$. AOAC procedures were used to assess the moisture, ether extract, raw protein and the ash [19]. The total lipids were extracted according to the method of Folch [21], using a 2:1 chloroform/methanol $(v / v)$ solution to determine the fatty acid profile. The fatty acids were then methylated using a $\mathrm{KOH} /$ methanol $2 \mathrm{~N}$ solution [22] and analyzed by gas chromatography (Shimadzu GC-17A) using a silicone-glass capillary column (70\% Cyanopropyl Polysilphenylenesiloxane BPX 70 by Thermo Scientific, length $=60 \mathrm{~m}$, internal diameter $=0.25 \mathrm{~mm}$, film thickness $=0.25 \mu \mathrm{m}$ ). The starting temperature was $135^{\circ} \mathrm{C}$ for $7 \mathrm{~min}$, then increased by $4{ }^{\circ} \mathrm{C} / \mathrm{min}$ up to $210^{\circ} \mathrm{C}$, with a linear velocity near to $37 \mathrm{~cm} / \mathrm{s}$. Fatty acids were identified by comparison of retention times to authentic standards (Food industry FAME mix, Restek Corporation, Bellefonte, PA, USA) for percentage area normalization. Relative quantities are expressed as weight percentage $(\mathrm{wt} / \mathrm{wt})$ of total methylated fatty acids.

The food risk factors of meat were determined by calculating the Atherogenic (A.I.) and Thrombogenic (T.I.) Indexes [23]:

$$
\text { A.I. }=[(C 12: 0+4 \times C 14: 0+C 16: 0)] \div[\Sigma M U F A+\Sigma n-6+\Sigma n-3] ;
$$

T.I. $=[(C 14: 0+C 16: 0+C 18: 0)] \div[(0.5 \times \Sigma M U F A+0.5 \times \Sigma \mathrm{n}-6+3 \times \Sigma \mathrm{n}-3+\Sigma \mathrm{n}-3) / \Sigma \mathrm{n}-6] ;$

where MUFA are monounsaturated fatty acids.

Fatty acids were expressed as a percentage (wt/wt) of total methylated fatty acids.

\subsection{Statistical Analysis}

The collected data were analyzed using the general linear procedure (GLM). This is a procedure of the SAS application package [24]. Differences among treatments mean, for significant origin effects, were detected and compared by Tukey's HSD.

\section{Results and Discussion}

\subsection{Biometric Parameters}

The morphometric parameters and biometric indexes are shown in Table 2. Although no statistically significant difference in the total body weight was observed between the three groups, total body length and fork length are significantly higher in wild sea bass than in the other two. 
Table 2. Morphometric and biometric indices for each rearing system of sea bass.

\begin{tabular}{cccccc}
\hline & Origin & & \\
\hline & $\begin{array}{c}\text { ES } \\
(\boldsymbol{n}=\mathbf{2 5})\end{array}$ & $\begin{array}{c}\text { IRS } \\
(\boldsymbol{n}=\mathbf{2 5})\end{array}$ & $\begin{array}{c}\text { WF } \\
(\boldsymbol{n}=\mathbf{2 5})\end{array}$ & SEM & $p$ Value \\
\hline Total body weight $(\mathrm{g})$ & 292.65 & 325.90 & 347.97 & 32.54 & 0.655 \\
\hline Total body length $(\mathrm{cm})$ & $30.77 \mathrm{~B}$ & $30.92 \mathrm{~B}$ & $32.64 \mathrm{~A}$ & 0.87 & 0.007 \\
\hline Fork length $(\mathrm{cm})$ & $29.36 \mathrm{~B}$ & $29.45 \mathrm{~B}$ & $31.00 \mathrm{~A}$ & 0.94 & 0.004 \\
\hline Viscera $(\%$ of TBW) & 5.28 & 8.28 & 5.51 & 1.21 & 0.065 \\
\hline Relative profile & $22.27 \mathrm{~b}$ & $23.14 \mathrm{a}$ & $22.31 \mathrm{~b}$ & 1.04 & 0.022 \\
\hline Cranial index & $26.84 \mathrm{~A}$ & $25.10 \mathrm{~B}$ & $26.58 \mathrm{~A}$ & 0.88 & 0.002 \\
\hline Condition factor & $1.15 \mathrm{~B}$ & $1.28 \mathrm{~A}$ & $1.17 \mathrm{~B}$ & 0.08 & 0.004 \\
\hline Carcass yield $(\%)$ & $94.72 \mathrm{~A}$ & $91.72 \mathrm{~B}$ & $94.49 \mathrm{~A}$ & 1.21 & 0.009 \\
\hline Edible yield $(\%)$ & 56.55 & 56.77 & 56.70 & 2.17 & 0.078
\end{tabular}

ES: extensive system; IRS: intensive rearing system; WF: wild fish; SEM: Standard error of means; a, b: $p<0.05 ; \mathrm{A}$ B: $p<0.01$.

The biometric indexes resulted significantly affected by the rearing system, this occurs due to altered stocking densities, swimming capacity, quality and quantity of food requested [25]. Fishes from the Intensive rearing system showed the highest value of relative profile $(p=0.022)$ and condition factor $(p=0.004)$ and the lowest value of the cranial index $(p=0.002)$. The same group recorded the lowest value of carcass yield $(p=0.009)$, whereas the value of edible yield was uniform in the groups. Our results are more similar to Tulli [26] and Di Turi [27], who investigated growth performance and biometry traits of sea bass from different farming systems.

\subsection{Proximate Composition}

The chemical composition depends on many factors including culture environment, the region of fishing, season and nutrition habits. In the present study, IRS fillets are characterized by a significantly higher content of protein $(p=0.008)$, lipid $(p=0.006)$, ash $(p=0.009)$ and $\mathrm{N}$ free extract $(p=0.037)$ (Table 3). Consequently, we obtain a lower amount of moisture compared with the other two groups $(p=0.003)$.

Table 3. Proximate composition of fillet of sea bass for each rearing system (\%).

\begin{tabular}{cccccc}
\hline & Origin & & \\
\hline & $\begin{array}{c}\text { ES } \\
(n=25)\end{array}$ & $\begin{array}{c}\text { IRS } \\
(n=25)\end{array}$ & $\begin{array}{c}\text { WF } \\
(n=25)\end{array}$ & SEM & $p$ Value \\
\hline Moisture & $77.33 \mathrm{~A}$ & $73.07 \mathrm{~B}$ & $76.75 \mathrm{~A}$ & 0.684 & 0.003 \\
\hline Crude Protein & $19.65 \mathrm{~B}$ & $21.39 \mathrm{~A}$ & $19.95 \mathrm{~B}$ & 0.145 & 0.008 \\
\hline Lipid & $1.23 \mathrm{~B}$ & $3.05 \mathrm{~A}$ & $1.04 \mathrm{~B}$ & 0.155 & 0.006 \\
\hline Ash & $1.50 \mathrm{~B}$ & $1.64 \mathrm{~A}$ & $1.46 \mathrm{~B}$ & 0.030 & 0.009 \\
\hline N free-extract & $0.60 \mathrm{~b}$ & $0.87 \mathrm{a}$ & $0.95 \mathrm{a}$ & 0.100 & 0.037
\end{tabular}

ES: extensive system; IRS: intensive rearing system; WF: wild fish; SEM: Standard error of means; a, b: $p<0.05 ; \mathrm{A}$, B: $p<0.01$.

The difference in the mean total lipid content was particularly marked between wild and IRS sea bass $(1.04 \%$ vs. $3.05 \% ; p=0.006)$. Higher fat levels in farmed fish compared with wild fish have also been observed for sea bass [28,29] and other fish species [30-32].

Periago [33] and Fuentes [8] in a comparison of wild and farmed sea bass, showed the highest value of moisture and protein in farmed sea bass and a higher total fat in wild sea bass. In the same comparison, Baki [34] showed a higher value of moisture, crude protein and crude lipid in cultured sea bass.

This result could be due to a variety of factors including availability and type of food, dietary ingredients (commercial diets are usually high in fat content and also include dietary carbohydrate), and reduced activity of the cultured fish $[33,34]$. 


\subsection{Fatty Acid Profiles of Fillets}

The fatty acid profiles of total lipids extracted from three groups of sea bass are reported in Table 4. Concerning the wild sea bass, there is a lack of information about their genetic lineage and age, as well as the environmental and nutritional parameters affecting these fish during ontogeny. This makes it quite difficult to find a unique or direct explanation for their results of fatty acid composition.

Table 4. Fatty acid profile of fillet of sea bass for each rearing system (\% of total FA methyl esters).

\begin{tabular}{|c|c|c|c|c|c|}
\hline \multicolumn{6}{|c|}{ Origin } \\
\hline & $\begin{array}{c}\text { ES } \\
(n=25)\end{array}$ & $\begin{array}{c}\text { IRS } \\
(n=25)\end{array}$ & $\begin{array}{c}\text { WF } \\
(n=25)\end{array}$ & SEM & $p$ Value \\
\hline C12:0 (lauric) & $0.07 \mathrm{ab}$ & $0.06 \mathrm{~b}$ & $0.08 \mathrm{a}$ & 0.01 & 0.034 \\
\hline C14:0 (myristic) & $4.04 \mathrm{~B}$ & $5.56 \mathrm{~A}$ & $2.23 \mathrm{C}$ & 0.15 & 0.004 \\
\hline C15:0 (pentadecanoic) & $0.50 \mathrm{~B}$ & $0.56 \mathrm{~b}$ & $0.67 \mathrm{Aa}$ & 0.03 & 0.003 \\
\hline C16:0 (palmitic) & 21.96 & 21.98 & 22.99 & 0.50 & 0.058 \\
\hline C17:0 (heptadecanoic) & $0.47 \mathrm{Bc}$ & $0.55 \mathrm{~b}$ & $0.65 \mathrm{Aa}$ & 0.02 & 0.001 \\
\hline C18:0 (stearic) & $4.93 \mathrm{~B}$ & $3.88 \mathrm{C}$ & $6.65 \mathrm{~A}$ & 0.13 & 0.002 \\
\hline$\sum$ SFA $^{1}$ & 31.98 & 32.60 & 33.27 & 0.66 & 0.087 \\
\hline C16:1 n9 & $0.69 \mathrm{C}$ & $0.86 \mathrm{~B}$ & $0.97 \mathrm{~A}$ & 0.03 & 0.002 \\
\hline C16:1 n7 (palmitoleic) & $5.63 \mathrm{~B}$ & $7.20 \mathrm{~A}$ & $7.37 \mathrm{~A}$ & 0.19 & 0.006 \\
\hline C17:1 & $0.33 \mathrm{Bc}$ & $0.46 \mathrm{~b}$ & $0.63 \mathrm{Aa}$ & 0.04 & 0.002 \\
\hline C18:1 n9 (oleic) & $21.59 \mathrm{a}$ & $20.24 \mathrm{~b}$ & $20.54 a b$ & 0.40 & 0.039 \\
\hline $\mathrm{C} 18: 1 \mathrm{n} 7$ & $3.12 \mathrm{~B}$ & $3.22 \mathrm{~B}$ & $4.88 \mathrm{~A}$ & 0.07 & 0.005 \\
\hline C20:1 n9 (eicosanoic) & $3.47 \mathrm{~B}$ & $4.44 \mathrm{~A}$ & $1.41 \mathrm{C}$ & 0.08 & 0.005 \\
\hline$\sum$ MUFA $^{2}$ & 34.84 & 36.41 & 35.80 & 0.59 & 0.077 \\
\hline C18:2 n6 (linoleic) & $7.65 \mathrm{~A}$ & $5.06 \mathrm{~B}$ & $2.24 \mathrm{C}$ & 0.20 & 0.007 \\
\hline C18:3n6 ( $\gamma$-linolenic) & $0.53 \mathrm{~B}$ & $0.57 \mathrm{~B}$ & $0.75 \mathrm{~A}$ & 0.02 & 0.001 \\
\hline C18:3n3 ( $\alpha$-linolenic) & 1.01 & 0.90 & 0.78 & 0.10 & 0.082 \\
\hline $\mathrm{C} 18: 4 \mathrm{n} 3$ & $0.94 \mathrm{~B}$ & $1.68 \mathrm{~A}$ & $0.85 \mathrm{~B}$ & 0.09 & 0.003 \\
\hline C20:4 n6 (arachidonic) & $2.60 \mathrm{C}$ & $3.70 \mathrm{~B}$ & $4.28 \mathrm{~A}$ & 0.14 & 0.006 \\
\hline $\mathrm{C} 20: 4 \mathrm{n} 3$ & $1.00 \mathrm{~A}$ & $0.55 \mathrm{~B}$ & $0.52 \mathrm{~B}$ & 0.05 & 0.004 \\
\hline C20:5 n3 (eicosapentaenoic, EPA) & $5.61 \mathrm{c}$ & $6.74 \mathrm{a}$ & $6.09 \mathrm{~b}$ & 0.33 & 0.024 \\
\hline C22:5 n6 (docosapentaenoic, DPA) & $0.43 \mathrm{~B}$ & $0.23 \mathrm{C}$ & $1.05 \mathrm{~A}$ & 0.05 & 0.003 \\
\hline $\mathrm{C} 22: 5 \mathrm{n} 3$ & $1.28 \mathrm{~B}$ & $1.14 \mathrm{~B}$ & $2.31 \mathrm{~A}$ & 0.09 & 0.004 \\
\hline C22:6 n3 (docosahexaenoic, DHA) & $12.13 \mathrm{a}$ & $10.42 \mathrm{~b}$ & $12.05 \mathrm{a}$ & 0.68 & 0.036 \\
\hline Total n- $6^{3}$ & $11.21 \mathrm{~A}$ & $9.54 \mathrm{~B}$ & $8.32 \mathrm{C}$ & 1.06 & 0.008 \\
\hline Total n-3 ${ }^{4}$ & 21.97 & 21.45 & 22.61 & 0.19 & 0.084 \\
\hline$\sum$ PUFA $^{5}$ & 33.18 & 30.98 & 30.93 & 1.11 & 0.102 \\
\hline$\sum \mathrm{UFA}^{6}$ & 68.02 & 67.39 & 66.73 & 0.85 & 0.097 \\
\hline$n-6 / n-3$ & $0.51 \mathrm{~A}$ & $0.45 \mathrm{~B}$ & $0.37 \mathrm{~B}$ & 0.04 & 0.009 \\
\hline A.I. ${ }^{7}$ & $0.56 \mathrm{~b}$ & $0.66 \mathrm{a}$ & $0.55 \mathrm{~b}$ & 0.05 & 0.045 \\
\hline T.I. ${ }^{8}$ & 0.34 & 0.35 & 0.35 & 0.01 & 0.061 \\
\hline
\end{tabular}

ES: extensive system; IRS: intensive rearing system; WF: wild fish; SEM: Standard error of means; $\mathrm{a}, \mathrm{b}: p<0.05$ A, B: $p<0.01 ;{ }^{1} \sum$ SFA-saturated fatty acids (sum of C12:0 + C14:0 + C15:0 + C16:0 + C17:0 + C18:0) ${ }^{2} \sum$ MUFA-monounsaturated fatty acids (sum of C16:1 n9 + C16:1 n7 + C17:1+C18:1n9+ C18:1 n7 + C20:1 n9); ${ }^{3}$ Total n-6 (sum of C18:2 n6 + C18:3 n6 +C20:4 n6 + C22:5 n6); ${ }^{4}$ Total n-3 (sum of C18:3 n3+C18:4n3 + C20:4 n3 + $\mathrm{C} 20: 5 \mathrm{n} 3+\mathrm{C} 22: 5 \mathrm{n} 3+\mathrm{C} 22: 6 \mathrm{n} 3) ;{ }^{5} \sum$ PUFA—polyunsaturated fatty acids (sum of n- $6+\mathrm{n}-3$ ) $;{ }^{6} \sum$ UFA - unsaturated fatty acids (sum of MUFA + PUFA); ${ }^{7}$ A.I.-atherogenic index; ${ }^{8}$ T.I.- thrombogenic index; $\mathrm{a}, \mathrm{b}, \mathrm{c}: p<0.05 ; \mathrm{A}, \mathrm{B}, \mathrm{C}$ : $p<0.01$. 
Even if the date has no statistical significance, the totality of the saturated fatty acids was higher in wild fish fillets. Moreover, the same trend agrees with results for sea bass and other fish species [8,33-36]. Palmitic acid (C16:0) was the primary SFA in all samples, followed by stearic acid (C18:0), with these contents being higher in wild fish as the content of C12:0 $(p=0.002), C 15: 0(p=0.003)$ and C17:0 $(p=0.001)$. On the contrary, WF recorded the lowest value of C14:0 (2.23\% vs. $4.04 \%$ and $5.56 \% ; p=0.004)$.

Fillets of extensive reared sea bass showed the lowest value of C16:1n9 $(p=0.002)$, $\mathrm{C} 16: 1 \mathrm{n} 7(p=0.006), \mathrm{C} 17: 1(p=0.002), \mathrm{C} 18: 1 \mathrm{n} 7(p=0.005)$, and the highest $(p=0.005)$ value of oleic acid (C18:1 n9), who was identified as the major monounsaturated fatty acid in cultured and wild sea bass [37-39].

With regard to PUFA, sea bass can be considered as a good source of the n-3 series fatty acids, particularly of eicosapentaenoic acid (EPA) and docosahexaenoic acid (DHA), showing the highest $(p=0.024$ and $p=0.036)$ levels in wild specimens, which agrees with those of Alasalvar [40]. DHA, playing a fundamental role in brain and retina development during the early stages of human life, was present in wild and farmed sea bass at comparably high levels [14,41]. EFSA has carried out a number of scientific assessments of health claims related to the benefits of n-3 LCPUFA intake. The Panel on Dietetic Products, Nutrition and Allergies (NDA Panel) has concluded that intakes of EPA and DHA of between $2 \mathrm{~g}$ and $4 \mathrm{~g}$ a day are needed to reach claimed effects such as the maintenance of blood pressure and triglyceride levels, and intakes of $250 \mathrm{mg}$ a day are sufficient for the maintenance of normal cardiac function [42]. WF flesh have EPA and DHA values in accordance with this recommendation.

Arachidonic acid (C20:4 n6) was found at significantly higher levels in wild fish $(p=0.006)$, whereas its precursor, linolenic acid (C18:2 n6), accumulated in extensive farmed fish $(p=0.007)$. A scarce metabolic action of the latter, due to a feedback inhibition exerted on $\Delta 6$-desaturase by the $n-3$ polyunsaturated fatty acids, abundantly supplied with the diet, maybe the reason for the low presence of arachidonic acid in farmed fish [14,43].

The fatty acid profiles of wild sea bass, selecting different organisms from the aquatic environment as their natural diet sources, showed species-specific patterns that were, at a certain extent, less evident in intensively reared fish fed commercial diets with similar chemical composition. Some of the differences found between the fatty acid profiles of wild and farmed fish of either species may be attributed to the different dietary regimen followed by fish in the salt lake and in intensive farming. In fact, although fish from the salt lake drew nutrients from the natural resources of their habitat, whose availability presumably varied, farmed fish received always the same diet containing fish and thus being rich in n-3 long-chain polyunsaturated fatty acids.

There is no significant difference between wild and farmed sea bass fillets as regard the total n-3 polyunsaturated fatty acids. However, a significantly higher percentage of total n-6 PUFA was found in lipids of extensively reared fishes in comparison with the other two groups. This value influenced the ratio n-6/n-3 $(p=0.009)$; in fact, the ES group showed a higher value in comparison with the WF ones.

Mammalian cells cannot convert n- 6 to n-3 fatty acids because they lack the converting enzyme, n-3 desaturase. n-6 and n-3 fatty acids are not interconvertible, are metabolically and functionally distinct, and often have important opposing physiological effects; therefore, their balance in the diet is important. When humans ingest fish or fish oil, the EPA and DHA from the diet partially replace the n-6 fatty acids, especially arachidonic acid, in the membranes of probably all cells, but especially in the membranes of platelets, erythrocytes, neutrophils, monocytes, and liver cells [44].

As Orban hypothesized [14], a higher intake of preformed long-chain PUFA (such as fish meal and fish oil) in farmed fish and a different capability of sea bass to desaturate and elongate C18 PUFA could explain the low levels of PUFA found in wild sea bass. There is a need of a deeper understanding and knowledge on the fatty acid composition and the natural diet of the fish which lives in the salt lake to confirm this hypothesis. The use of formulated feeds rich in n-3 PUFA in aquaculture-desirable from a human 
nutritional standpoint in consideration of the role played by n-3 PUFA in the prevention of cardiovascular and inflammatory diseases-also has a positive incidence on the growth rate and feed conversion efficiency of fish [14,39].

The indices of atherogenicity and of thrombogenicity are indicators assessing the level and the interrelation of some fatty acids that have effects on the occurrence of coronary heart diseases [23]. In this study, the lipids from fillets of reared sea bass showed a markedly greater atherogenic $(p=0.045)$ compared with the other two groups, the result that confirms that the WF flesh has the most beneficial parameters, but using formulated feeds rich in n-3 PUFA in aquaculture-farmed sea bass could be close to optimal values for human health.

Aside from the relative proportions of fatty acids in total lipids, which allowed a direct comparison of the lipid quality of fish from different sources, an estimation of the actual contents of total n-3 and n-6 PUFA in fish flesh also has an importance in view of its human consumption. In this study, because of the higher total lipid content, farmed sea bass showed higher levels of total n-3 and n-6 PUFA in their muscles compared to their wild counterparts. This observation has important nutritional implications considering that about $9.2 \%$ of the total marine fish purchased by Italian families in the year 2020 was represented by sea bass [45].

\section{Conclusions}

This study provides useful indications on the distinctive elements characterizing the nutritional quality of sea bass produced in Italy by intensive farming and grown in natural salt lake environments.

Our results demonstrate that intensive rearing system significantly influence the biometric indexes such as relative profile, condition factor and carcass yield. Fish fillets from the intensive group showed a higher quantity of crude protein and had a triple amount of fat compared with WF ones, characterized by similar values of SFA, MUFA and PUFA.

As we expected, the proximate composition and the fatty acid profile of fillets of reared sea bass were similar to the wild ones; the only significant difference was found in total n-6, higher in intensive reared sea bass flesh than wild ones, that influenced the higher values atherogenic index.

As far as n-6 to n-3 ratio is concerned, the 2002 Joint WHO/FAO Expert Consultation on Diet, Nutrition and the Prevention of Chronic Diseases and its background scientific review had indicated a balanced intake of n-6 and n-3 PUFAs is essential for health [46]; our results showed that all the flesh analyzed were characterized by optimal value of $\mathrm{n}-6 / \mathrm{n}-3$ ratio.

The values showed in our trial ensure the high quality of reared sea bass fillets, that can be considered as indicated for human consumption as a healthy alternative to the wild fishes.

Author Contributions: Conceptualization, P.C.; Data curation, S.T.; Formal analysis, P.C. and S.T.; Funding acquisition, A.C.J.; Investigation, P.C. and M.R.; Methodology, P.C., M.R. and S.T.; Resources, A.C.J.; Supervision, M.R.; Writing-original draft, S.T. and M.R.; Writing-revised paper, S.T. and M.R. All authors have read and agreed to the published version of the manuscript.

Funding: This work was supported by Regione Puglia (ITALY)—Progetto FEAMP “Salvaguardia di piccoli pelagici: Una pesca sostenibile ed innovativa nel Basso Adriatico" (SALV.ADRI); CUP: B91B17001140009.

Institutional Review Board Statement: Our research does not fall under the legislation for the protection of animals used for scientific purposes, national decree-law 113/2013 (2010-63-EU directive).

Acknowledgments: The authors express their gratitude to the technicians of the Department of Agricultural and Environmental Science Massimo Lacitignola, Nicolò Devito and Domenico Gerardi for their laboratory assistance.

Conflicts of Interest: The authors declare no conflict of interest. 


\section{References}

1. Carminato, A.; Pascoli, F.; Trocino, A.; Locatello, L.; Maccatrozzo, L.; Palazzi, R.; Radaelli, G.; Ballarin, C.; Bortoletti, M.; Bertotto, D. Productive results, oxidative stress and contaminant markes in European Sea Bass: Conventional vs. organic feeding. Animals 2020, 10, 1226. [CrossRef]

2. Betancor, M.B.; MacEwan, A.; Sprague, M.; Gong, X.; Montero, D.; Han, L.; Napier, J.A.; Norambuena, F.; Izquierdo, M.; Tocher D.R. Oil from transgenic Camelina sativa as a source of EPA and DHA in feed for European sea bass (Dicentrarchus labrax L.). Aquaculture 2021, 530, 735759. [CrossRef] [PubMed]

3. Rodde, C.; de Verdal, H.; Vandeputte, M.; Allal, F.; Nati, J.; Besson, M.; Blasco, F.R.; Benzie, J.A.H.; McKenzie, D.J. An investigation of links between metabolic rate and feed efficiency in European sea bass Dicentrarchus labrax. J. Anim. Sci. 2021, 99, 152. [CrossRef] [PubMed]

4. Mozaffarian, D.; Prineas, R.J.; Stein, P.K.; Siscovick, D.S. Dietary fish and n-3 fatty acid intake and cardiac electrocardiographic parameters in humans. J. Am. Coll. Cardiol. 2006, 48, 478-484. [CrossRef] [PubMed]

5. Reader, M.B.; Steen, V.M.; Vollset, S.E.; Bjelland, I. Association between cod liver oil use and symptoms of depression: The hordal and health study. J. Affect. Disord. 2007, 101, 245-249. [CrossRef]

6. Badiani, A.; Stipa, S.; Bitossi, F.; Pirini, M.; Bonaldo, A.; Gatta, P.P.; Rotolo, M.; Testi, S. True retention of nutrients upon household cooking of farmed portion-size European sea bass (Dicentrarchus labrax L.). LWT_Food Sci. Technol. 2013, 50, 72-77. [CrossRef]

7. BØrrensen, T. Quality aspects of wild and reared fish. In Quality Assurance in the Food Industry; Huss, H.H., Jacobsen, M., Liston, J., Eds.; Elselvier: Amsterdam, The Netherlands, 1992; pp. 1-17.

8. Fuentes, A.; Fernandez-Segovia, I.; Serra, J.A.; Barat, J.M. Comparison of wild and cultured sea bass (Dicentrarchus labrax) quality. Food Chem. 2010, 119, 1514-1518. [CrossRef]

9. Pascon, G.; Messina, M.; Petit, L.; Pinheiro Valente, L.M.; Oliveira, B.; Przybyla, C.; Dutto, G.; Tulli, F. Potential application and beneficial effects of a marine microalgal biomass produced in a high-rate algal pond (HRAP) in diets of European sea bass, Dicentrarchus labrax. Environ. Sci. Pollut. Res. 2021, 28, 62185-62199. [CrossRef]

10. Katsika, L.; Huesca Flores, M.; Kotzamanis, Y.; Estevez, A.; Chatzifotis, S. Understanding the Interaction Effects between Dietary Lipid Content and Rearing Temperature on Growth Performance, Feed Utilization, and Fat Deposition of Sea Bass (Dicentrarchus labrax). Animals 2021, 11, 392. [CrossRef]

11. Kumar, N.; Chandan, N.K.; Gupta, S.K.; Bhushan, S.; Patole, P.B. Omega-3 fatty acids effectively modulate growth performance, immune response, and disease resistance in fish against multiple stresses. Aquaculture 2022, 547, 737506. [CrossRef]

12. Torrecillas, S.; Betancor, M.B.; Caballero, M.J.; Rivero, F.; Robaina, L.; Izquierdo, M.; Montero, D. Supplementation of arachidonic acid rich oil in European sea bass juveniles (Dicentrarchus labrax) diets: Effects on growth performance, tissue fatty acid profile and lipid metabolism. Fish Physiol. Biochem. 2018, 44, 283-300. [CrossRef]

13. Mastoraki, M.; Mollá Ferrándiz, P.; Vardali, S.C.; Kontodimas, D.C.; Kotzamanis, Y.P.; Gasco, L.; Chatzifotis, S.; Antonopoulou, E. A comparative study on the effect of fish meal substitution with three different insect meals on growth, body composition and metabolism of European sea bass (Dicentrarchus labrax L.). Aquaculture 2020, 528, 735511. [CrossRef]

14. Orban, E.; Nevigato, T.; Di Lena, G.; Casini, I.; Marzetti, A. Differentiation in the lipid quality of wild and farmed seabass (Dicentrarchus labrax) and gilthead sea bream (Sparum aurata). J. Food Sci. 2003, 68, 128-132. [CrossRef]

15. Munekata, P.E.S.; Pateiro, M.; Domínguez, R.; Zhou, J.; Barba, F.J.; Lorenzo, J.M. Nutritional Characterization of Sea Bass Processing By-Products. Biomolecules 2020, 10, 232. [CrossRef] [PubMed]

16. Izquierdo, M.S.; Obach, A.; Arantzamendi, L.; Montero, D.; Robaina, L.; Rosenlund, G. Dietary lipid sources for sea bream and sea bass: Growth performance, tissue composition and flesh quality. Aquac. Nutr. 2003, 9, 397-407. [CrossRef]

17. Dernekbaş, S.; Karayücel, I. Effect of alternate feeding with fish oil- and peanut oil-based diets on the growth and fatty acid compositions of European seabass fingerlings (Dicentrarchus labrax) in the recirculated systems. Aquac. Res. 2021, 52, 3137-3147. [CrossRef]

18. Available online: https://www.oie.int/en/what-we-do/standards/codes-and-manuals/aquatic-code-online-access / (accessed on 30 April 2021).

19. AOAC. Official Methods of Analysis of the AOAC. In Association of Official Agricultural Chemistry, 17th ed.; Association of Official Analytical Chemists: Arlington, VA, USA, 2000.

20. Cagnetta, P.; Zezza, L.; Bongermino, L.; Demetrio, G. Caratteristiche corporee e resa in porzione edule di spigola (Dicentrarchus labrax) proveniente da due diverse tipologie di allevamento. In Proceedings of the Atti Convegno Internazionale "Parliamo di ... Acquacoltura", Fossano, Italy, 13-14 October 1994; pp. 237-244. (In Italian).

21. Folch, J.; Less, M.; Sloane-Stanley, G.H. A simple method for isolation and purification of total lipids from animal tissues. J. Biol. Chem. 1957, 226, 497-509. [CrossRef]

22. Christie, W.W. Lipid Analysis-Isolation, Separation, Identification and Structural Analysis of Lipids; Pergamon: Oxford, UK, 1982; p. 270.

23. Ulbricht, T.L.V.; Southgate, D.A.T. Coronary heart disease: Seven dietary factors. Lancet 1991, 338, 985-992. [CrossRef]

24. SAS. SAS/STAT User's Guide: Statistics; SAS Institute Inc.: Cary, NC, USA, 2000.

25. Favaloro, E.M.; Mazzolla, A. Shape change during the growth of sharpsnout seabream reared under different conditions in a fish farm of southern Tyrrenian Sea. Aqualcult. Eng. 2003, 29, 57-63. [CrossRef] 
26. Tulli, F.; Balenovic, I.; Messina, M.; Tibaldi, E. Biometry traits and geometric morphometrics in sea bass (Dicentrarchus labrax) from different farming systems. Ital. J. Anim. Sci. 2009, 8, 881-883. [CrossRef]

27. Di Turi, L.; Ragni, M.; Caputi Jambrenghi, A.; Lastilla, M.; Vicenti, A.; Colonna, M.A.; Giannico, F.; Vonghia, G. Effect of dietary rosemary oil on growth performance and flesh quality of farmed seabass (Dicentrarchus labrax). Ital. J. Anim. Sci. 2009, 8, 857-859. [CrossRef]

28. Alasalvar, C.; Taylor, K.D.A.; Zubcov, E.; Shahidi, F.; Alexis, M. Differentiation of cultured and wild sea bass (Dicentrarchus labrax): Total lipid content fatty acid and trace mineral composition. Food Chem. 2002, 79, 145-150. [CrossRef]

29. Orban, E.; Lena, G.D.; Nevigato, T.; Casini, I.; Santaroni, G.; Marzetti, A.; Caproni, R. Quality characteristics of sea bass intensively reared and from lagoon as affected by growth conditions and the aquatic environment. J. Food Sci. 2002, 67, 542-546. [CrossRef]

30. Grigorakis, K.; Alexis, M.N.; Taylor, K.A.; Hole, M. Hole Comparison of wild and cultured gilthead sea bream (Sparus aurata): Composition, appearance and seasonal variations. Intern. J. Food Sci. Tech. 2002, 37, 477-484. [CrossRef]

31. Grigorakis, K.; Alexis, M.N.; Taylor, K.A.; Hole, M. Alexis Organoleptic and volatile aroma compounds comparison of wild and cultured gilthead sea bream (Sparus aurata): Sensory differences and possible chemical basis. Aquaculture 2003, 225, 109-119. [CrossRef]

32. Johnston, I.A.; Li, X.; Vieira, V.L.; Nickell, D.; Dingwall, A.; Alderson, R.; Campbell, P.; Bickerdike, R. Alderson Muscle and flesh quality traits in wild and farmed Atlantic salmon. Aquaculture 2006, 256, 323-336. [CrossRef]

33. Periago, M.J.; Ayala, M.D.; Lopez-Albors, O.; Abdel, I.; Martinez, C.; Garcia-Alcazar, A.; Ros, G.; Gil, F. Muscle cellularity and flesh quality of wild and farmed sea bass, Dicentrarchus labrax L. Aquaculture 2005, 249, 175-188. [CrossRef]

34. Baki, B.; Gönener, S.; Kaya, D. Comparison of food, amino acid and fatty acid compositions of wild and cultivated sea bass (Dicentrarchus labrax L., 1758). Turk. J. Fish. Aquat. Sci. 2015, 15, 175-179.

35. Magalhãesa, R.; Guardiola, F.A.; Guerreiro, I.; Fontinha, F.; Moutinho, S.R.; Lsen, E.O.; Peres, H.; Oliva-Telesa, A. Effect of different dietary arachidonic, eicosapentaenoic, and docosahexaenoic acid content on selected immune parameters in gilthead sea bream (Sparus aurata). Fish Shellfish Immunol. Rep. 2021, 2, 100014. [CrossRef]

36. Aydın, B. A preliminary assessment of the effects of dietary black cumin seed cake on growth performance, serum biochemical parameters and fatty acid composition of mirror carp (Cyprinus carpio var. specularis) fingerlings. Aquac. Rep. 2021, 21, 100847. [CrossRef]

37. Pirini, M.; Gatta, P.P.; Testi, S.; Trigari, G.; Monetti, P.G. Effect of refrigerate storage on muscle lipid quality of sea bass (Dicentrarchus labrax) fed on diets containing different levels of vitamin E. Food Chem. 2000, 68, 289-293. [CrossRef]

38. Dernekbaşı, S.; Karayücel, I.; Karataş, E.; Akyüz, A.P. Potential of Using Peanut Oil as Alternative to Fish Oil for European Seabass Diets (Dicentrarchus Labrax) in Recirculated Systems. Alinteri J. Agric. Sci. 2021, 36, 109-121. [CrossRef]

39. Terova, G.; Moroni, F.; Antonini, M.; Bertacchi, S.; Pesciaroli, C.; Branduardi, P.; Labra, D.; Porro, M.; Ceccotti, C.; Rimoldi, S Using Glycerol to Produce European Sea Bass Feed With Oleaginous Microbial Biomass: Effects on Growth Performance, Filet Fatty Acid Profile, and FADS2 Gene Expression. Front. Mar. Sci. 2021, 8, 715078. [CrossRef]

40. Alasalvar, C.; Taylor, K.D.A.; Öksüz, A.; Garthwaise, T.; Alexis, M.N.; Grigorakis, K. Freshness assessment of cultured sea bream (Sparus aurata) by chemical, physical and sensory methods. Food Chem. 2001, 72, 33-44. [CrossRef]

41. Tsopelakos, A.; Zogopoulou, E.; Panagiotaki, p.; Miliou, H. Combined effects of dietary n-3 long-chain polyunsaturated fatty acid levels and saturated to monounsaturated fatty acid ratio on growth, fillet composition and blood parameters of European sea bass, Dicentrarchus labrax L. Aquac. Res. 2021, 52, 5213-5228. [CrossRef]

42. Available online: https://www.efsa.europa.eu/en/press/news/120727 (accessed on 16 November 2021).

43. Gladyshev, M.I. Terrestrial Sources of Polyunsaturated Fatty Acids for Aquaculture. J. Ichth. Yol. 2021, 61, 632-645. [CrossRef]

44. Simopoulos, A.P. An increase in the omega-6/omega-3 fatty acid ratio increases the risk for obesity. Nutrients 2016, 8, 128. [CrossRef]

45. Annuario Settore Ittico. Available online: https://www.bmti.it/wp-content/uploads/2020/04/Le-principali-evidenze-per-ilsettore-ittico-nel-2019.pdf (accessed on 2 March 2021).

46. World Health Organization. Diet, Nutrition and the Prevention of Chronic Diseases: Report of a Joint WHO/FAO Expert Consultation; World Health Organization: Geneva, Switzerland, 2003; Volume 916, pp. 54-60. 